\title{
Kan lokalbaserte strategier bidra til å redusere sosiale helseforskjeller? MoRo-prosjektet - bakgrunn, hovedresultater og erfaringer
}

\author{
Anne Karen Jenum ${ }^{1}$, Catherine Lorentzen ${ }^{2}$, Sidsel Graff-Iversen ${ }^{3}$, Sigmund Anderssen ${ }^{2}$, \\ Ann Kristin Ødegaard ${ }^{4}$, Ingar Holme ${ }^{2}$, Kåre Birkeland ${ }^{1,5}$ og Yngvar Ommundsen ${ }^{2}$ \\ ${ }^{1}$ Diabetesforskningssenteret, Aker universitetssykehus \\ ${ }^{2}$ Norges Idrettshøgskole \\ ${ }^{3}$ Nasjonalt folkehelseinstitutt \\ ${ }^{4}$ Oslo kommune, bydel Grorud \\ ${ }^{5}$ Fakultetsdivisjonen Aker universitetssykehus, Universitetet i Oslo \\ Korrespondanse: Anne Karen Jenum, Diabetesforskningssenteret Aker universitetssykehus HF, 0514 Oslo \\ Telefon: 91181416 Telefaks: 22894155 E-post: a.k.jenum@medisin.uio.no
}

\begin{abstract}
SAMMENDRAG
I en multietnisk bydel i Oslo med høy dødelighet og lav sosioøkonomisk status ble en teoribasert befolkningsrettet intervensjon for å fremme fysisk aktivitet utviklet og evaluert. Alle i alderen 31-67 år i intervensjonsbydelen og et aldersmatchet utvalg i kontrollbydelen ble invitert til en helseundersøkelse i 2000, og 2950 (48\%) møtte. Store etniske forskjeller i diabetesforekomst ble funnet. I aldersgruppen 30-59 år var forekomsten hos sør-asiatiske kvinner $27,5 \%(95 \% \mathrm{KI} 18,1-36,9)$ og hos menn 14,3\% (8,0-20,7), mot 2,9\% (1,9-3,9) hos norske kvinner og 5,9\% $(4,2-7,5)$ hos menn. De etniske forskjellene var signifikante etter justering for alder, midje/hofteratio, fysisk aktivitet og utdanning. Etter ytterligere justering for kroppshøyde var OR for kvinner (også justert for paritet) 6,0 $(2,3-15,4)$ og for menn $1,9(0,9-4,0)$. En sterk invers assosiasjon mellom diabetes og utdanning og inntekt ble funnet hos de vestlige. Hos innvandrere ga økt inntekt økt risiko for diabetes. Etter intervensjonen møtte $67 \%$ til oppfølgingsundersøkelsen i 2003. Endringer i fysisk aktivitet, dagligrøyking og biologiske variabler ble beregnet hos dem som møtte begge ganger. Netto økning i fysisk aktivitet (forskjell i endring fra 2000-2003 mellom bydelene) $\operatorname{var} 9,5 \%(\mathrm{p}=0,008)$. Andel inaktive ble redusert med $22 \%$. Andelen som gikk opp i vekt, ble redusert med $50 \%$ i forhold til kontrollbydelen $(p<0,001)$. Gunstige effekter ble funnet for kolesterol/HDL-kolesterol ratio, triglyserider og glukose, systolisk blodtrykk og andel dagligrøykere. Resultatene for vekt, lipider og glukose var sammenlignbare for deltakere med høy og lav utdanning, og vestlig og ikke-vestlig bakgrunn. Teoribaserte intervensjoner for å endre atferd og biologiske risikofaktorer for hjerte- og karsykdom og diabetes i lokalsamfunn med høy dødelighet og lav sosioøkonomisk status, bør inngå i en nasjonal strategi for å redusere sosiale helseforskjeller.
\end{abstract}

Jenum AK, Lorentzen C, Graff-Iversen S, Anderssen S, Ødegaard AK, Holme I, Birkeland K, Ommundsen Y.

Can area-based public health strategies reduce the social gradient in health? The "Romsås in Motion" Study - background, main results and lessons learnt. Nor J Epidemiol 2007; 17 (1): 49-57.

\section{ENGLISH SUMMARY}

We developed and evaluated a community-based three year intervention to increase physical activity in a multiethnic urban district with high mortality rates and low socioeconomic status. A pseudo-experimental cohort design was used to compare changes in risk factors from an intervention and a control district with similar socioeconomic status in Oslo, Norway, using baseline investigation of 2,950 30-67 year old participants, and follow-up investigation of $67 \%$. A set of theory-based activities to promote physical activity were implemented, tailored towards groups with different psychosocial readiness for change. Large ethnic differences in diabetes prevalence were found at baseline. South Asians had the highest prevalence, with rates of $27.5 \%$ (95\% CI 18.1-36.9) for women and $14.3 \%$ (8.0-20.7) for men, compared with $2.9 \%$ (1.9-3.9) and 5.9\% (4.2-7.5) for Norwegian women and men. The ethnic differences were significant when adjusted for age, waist/hip ratio, physical activity and education. After additional adjustment for body height, and for women also for parity, OR's were 6.0 (2.3-15.4) for women and 1.9 (0.9-4.0) for men. A strong inverse association with diabetes and education and income was observed among westerners. Among the South Asians OR for diabetes increased with increased income. The results of the intervention are reported as net changes in behaviours and biological variables (the difference between changes in the intervention and control districts). The increase in physical activity was $9.5 \%(\mathrm{p}=0.008)$. The proportion who increased their body mass was $50 \%$ lower in the intervention district $(\mathrm{P}<0.001)$ compared with the control district. Beneficial effects were seen for cholesterol/HDL-cholesterol ratio, triglyceride levels, glucose, systolic blood pressure and daily smoking. The results were comparable for those with high and low education, and for westerners and nonwesterners. Through a theory-driven population-based intervention we observed an increase in physical activity levels, a reduced weight gain and beneficial changes in other risk factors for type 2 diabetes and cardiovascular disease in a multiethnic district with high mortality rates and low socioeconomic status. Effective area-based public health initiatives should be an integrated part of the Norwegian strategy to reduce the social gradient in health. 


\section{BAKGRUNN}

Parallelt med velstandsutviklingen etter siste verdenskrig ble den vestlige verden, riktignok i ulik grad, rammet av en rask økning i dødeligheten av koronarsykdom. I Norge nådde epidemien sitt toppnivå i 1970-årene. Den nasjonale innsatsen for å bekjempe epidemien må anses som vellykket. Dødelighetsratene er halvert siden 1970-årene for 40-69-åringer (1). Effekten kan tilskrives en kombinasjon av bedre forebygging og behandling på individnivå (høyrisikostrategi) og ernæringspolitiske virkemidler, restriksjoner på tobakksreklame og -bruk på offentlige arenaer og informasjon om risikofaktorer (befolkningsbasert strategi). Men effekten har vært forskjellig i ulike sosiale strata av befolkningen (2). Den sosiale gradient i dødelighet av koronarsykdom (3) og i røykevaner forklarer en betydelig del av de sosiale forskjellene i totaldødelighet i Norge (2). I senere tid har livsløpsperspektivet, som innbefatter påvirkning av sosiale forhold gjennom tid og rom, bidratt til større forståelse av hvordan kroniske sykdommer utvikles og den sosiale gradient $\mathrm{i}$ helse oppstår $(4,5)$.

Innen Oslo har markante regionale dødelighetsforskjeller vedvart fram til vår tid. Forventet levealder ved fødsel var 11 år kortere i 1990-1994 i bydeler i indre øst for menn og 7 år kortere for kvinner på Romsås enn i bydel Vinderen (6). Dødeligheten av hjerte- og karsykdommer var tre ganger høyere. Sammenhengen mellom bydelenes dødelighetsrater for hjerte- og karsykdommer, sosioøkonomiske faktorer og risikofaktorer, ble derfor undersøkt (7). Dødelighetsratene viste sterk korrelasjon med sosioøkonomiske indikatorer fra tidlig alder (proxy mål: gjennomsnittshøyde), tidlig voksen alder (andel i bydelene med lav utdanning) og aktuell livsfase (andel med høy inntekt). Risikofaktorer som røyking, fysisk inaktivitet og kroppsmasseindeks viste også sterk korrelasjon med sosioøkonomiske indikatorer fra flere livsfaser og med dødelighet av hjerte- og karsykdommer. Utdanning og inntekt forklarte en betydelig andel av variansen i mortalitetsrater mellom bydelene, men det gjorde også røykevaner. Ikke bare dødelighet, men også røykevaner synes å kunne spores til sosiale forhold i tidlig alder, også i Oslo (7). Analyser av utviklingen i risikofaktorer for hjerte- og karsykdom i bydelene i Oslo gjennom 1980og 1990-årene viste dessuten at kroppsmasseindeks og fysisk inaktivitet økte mer i østlige enn vestlige bydeler $(8,9)$.

Velferdspolitikken i etterkrigstiden hadde et helt annet primært siktemål enn å motvirke de helsemessig ugunstige effekter av den generelle velstandsutvikling. Store grupper av befolkningen i vestlige samfunn med lav sosial status har dårligere selvopplevd helse og mindre nedgang i sykelighet og dødelighet enn andre (2). Nå rammer diabetesepidemien og dens viktigste risikofaktorer fedme og fysisk inaktivitet ikke minst disse grupper $(10,11)$. Diabetes øker risikoen for hjerte-karsykdom 3-5 ganger justert for øvrige risiko- faktorer (12). Dagens trender for risikofaktorer og sykdom aktualiserer behovet for nye metoder også i det helsefremmende og forebyggende arbeidet for å redusere helsegradientene i fremtiden. En aktuell strategi er å påvirke helsedeterminanter som atferd, eller enda bedre, noen av de samfunnsmessige og sosiale faktorer som påvirker atferd, i en mer gunstig retning.

Bydel Romsås fikk mye negativ medieoppmerksomhet i 1990-årene for dårlige levekår og uhelse. Den høye dødeligheten må forstås i lys av langtidseffekter av sosioøkonomiske forhold, men også av ugunstig nivå for klassiske atferdsrelaterte risikofaktorer (7). "Mosjon på Romsås" (MoRo-prosjektet) er en befolkningsrettet intervensjonsstudie initiert for å redusere risikofaktorene for diabetes og hjerte-karsykdom i bydel Romsås, med en valgt bydel med tilsvarende befolkningssammensetning (Furuset) som kontroll $(8,9,13)$. Denne artikkelen presenterer hovedfunn fra MoRo-prosjektet 2000-2003, samt teorigrunnlaget og hovedstrategiene for den treårige intervensjonen.

\section{MATERIALE OG METODE}

Alle innbyggere i alderen 31-67 år i bydel Romsås ( $\mathrm{N}=$ 2955) og et aldersmatchet utvalg i bydel Furuset ( $\mathrm{N}=$ 3185) ble invitert til basisundersøkelsen i 2000. Datainnsamlingen er beskrevet tidligere (13) og fulgte $i$ hovedsak samme metode som de senere undersøkelser i Oslo (HUBRO) (14) og andre fylker (www.fhi.no). Informasjon om selvrapportert helse, levevaner og sosiale forhold ble innhentet ved spørreskjema som var oversatt til engelsk, urdu, tamil, tyrkisk og vietnamesisk. Høyde, vekt, livvidde, blodtrykk og hvilepuls ble målt og blodprøver tatt for analyse av lipider og glukose utført ved Ullevål universitetssykehus, Klinisk kjemisk avdeling. Alle med plasma glukose $\geq 6,1$ mmol/l ble bedt om å møte til fastende blodprøver (lipider, glukose og HbA1c (HPLC-metode), undersøkt ved Aker universitetssykehus, Klinisk kjemisk avdeling). Uoppdaget diabetes ble definert som fastende glukose $\geq 7,0 \mathrm{mmol} / 1$, eller fastende glukose 6,1-6,9 $\mathrm{mmol} / \mathrm{l}$ og HbAlc $>6,4 \%$, eller ikke-fastende glukose $\geq 11,1 \mathrm{mmol} / 1$ når deltaker ikke møtte til fastende prøver (13).

Deltakere fra 2000 som fortsatt levde og var bosatt i Oslo eller Akershus, ble invitert til oppfølgingsundersøkelsen i 2003 ( $\mathrm{N}=2644)$. Endringer i fysisk aktivitet (hard fysisk aktivitet $\mathrm{i}$ fritiden, kategorisert som: ingen, $<1$ time/uke, 1-2 t/uke, >3t/uke), vekt, systolisk blodtrykk, glukose, lipider og dagligrøyking hos dem som møtte begge ganger ble beregnet, samt gjennomsnittsendringer $\mathrm{i}$ bydelene og nettoendring $\mathrm{i}$ intervensjonsbydelen i forhold til kontrollbydelen (15). Prosjektet var godkjent av Regional forskningsetisk komite, og konsesjon fra Datatilsynet var innhentet.

Ved basisundersøkelsen ble frafallanalyser foretatt basert på SSB-data om sivilstand, etnisitet, utdanning, nettoinntekt og trygdestatus (13), og ved oppfølgingsundersøkelsen ved å sammenligne dem som kun møtte 
til basisundersøkelsen med dem som møtte begge ganger. Vanlige statistiske metoder ble benyttet $(13,15,16)$.

\section{Intervensjonen}

\section{Prosjektorganisering}

Gjennom dialog med lokalpolitikere i bydel Romsås startet samarbeidet om en systematisk satsning på helsefremmende og forebyggende arbeid ut fra kommunehelseloven (\$1-4), som pålegger helsetjenesten å ha oversikt over helsetilstanden i kommunen og faktorer som påvirker denne, og forutsetter at helsehensyn skal tas med i planlegging i alle sektorer. Fysisk aktivitet ble valgt som hovedstrategi for å redusere forekomsten av hjerte- og karsykdommer og diabetes. Kontakt med eksterne fagmiljøer ble etablert våren 1999. Representanter for befolkningen ble med i prosjektets styringsgruppe og var sterkt involvert i den videre utvikling, organisering og implementering av intervensjonen, likeledes alle fagavdelinger i bydelsadministrasjonen (9).

\section{Intervensjonens teorigrunnlag og hovedstrategier}

En rekke teorier og modeller er utviklet for å forklare forskjeller i helserelatert atferd mellom grupper og forutsetninger for endring i risikoatferd. Enkeltfaktorer fra flere av disse teoriene synes spesielt sentrale for å fremme fysisk aktivitet (17). Sosialkognitive teorier legger vekt på samspillet mellom faktorer på individnivå og i de nærmeste sosiale omgivelsene som bestemmende for helseatferd. Mestringsforventninger, dvs. individets tro på at det vil klare å utføre en bestemt atferd, anses særlig relevant, og stimuleres av mestringsopplevelser og modellæring (18). Opplevd støtte til å være fysisk aktiv fra personer i ens nærmeste omgivelser er positivt relatert til aktivitetsnivå (17). Flere teorier trekker også frem betydningen av holdningsendringer som forutsetning for å lykkes med atferdsendringer (19). Kommunikasjonsteorier hevder at et budskap må kunne fange personers oppmerksomhet, bli forstått og akseptert før eventuelle holdningsendringer. I den senere tid har studier antydet at identitet knyttet til fysisk aktivitet og faktisk atferd gjensidig påvirker hverandre (20). Videre fremholder sosioøkologiske modeller at også objektive faktorer i de fysiske omgivelsene, som tilgang til aktivitetsarenaer, og subjektive oppfatninger av disse, påvirker individets aktivitetsatferd (17). Implementering av multiple tiltak på mange påvirkningsnivåer vil øke sannsynligheten for varige endringer i atferd (21).

Stadiemodellen for atferdsendring fremhever betydningen av å tilpasse tiltak og strategier til personers og gruppers motivasjonelle beredskap for fysisk aktivitet (22). Aktiv medvirkning av representanter for målgruppen i utvikling, implementering og evaluering av intervensjonen ("empowerment") for bedre tilpasning til lokale behov, ønsker, ressurser og barrierer, samt økt identifisering med prosjektet, vil øke sannsynligheten for deltakelse og langvarig atferdsendring (23).
Hovedmålgruppen for intervensjonen i MoRoprosjektet var fysisk inaktive og lite aktive voksne. En rekke strategier og tiltak ble utviklet basert på overnevnte teorier og modeller for å fremme fysisk aktivitet både $\mathrm{i}$ den generelle befolkningen og hos personer med høy risiko for diabetes og hjerte- og karsykdommer, identifisert gjennom basisundersøkelsen $(9,15)$. Tiltakene omfattet bl.a. informasjonsformidling via ulike kanaler om temaet "fysisk aktivitet og helse", grupperettede aktivitetstilbud, en merket "Folkesti" i nærmiljøet, og brøyting, strøing og økt belysning av gangveier på vinteren (figur 1). Tiltakene ble implementert gradvis for å oppnå synergieffekter. I høyrisikointervensjonen inngikk også individuell oppfølging i regi av helsepersonell. I henhold til teorigrunnlaget er effektene av tiltakene på de antatte psykososiale mediatorene for endring $\mathrm{i}$ atferd og de ulike tiltakenes relative betydning vurdert, men dette omtales ikke her (selvstendig doktorgradsarbeid).

\section{RESULTATER}

\section{Sammenligning av bydelene for intervensjonen}

Av de 6140 inviterte møtte 2950 (48\%), 50,7\% i intervensjonsbydelen og 45,6\% i kontrollbydelen. Det var ingen forskjell mellom bydelene ved studiestart $\mathrm{i}$ alder, andel kvinner, andel ikke-vestlige innvandrere, andel inaktive, andel med selvrapportert hjerteinfarkt, angina eller diabetes eller total diabetesforekomst (tabell 1). Utdanningsnivået var imidlertid noe lavere, og andel dagligrøykere og andel med fedme noe høyere $\mathrm{i}$ intervensjonsbydelen enn i kontrollbydelen. Selv om andelen med lav utdanning var noe høyere blant de ikke-møtte, ble det ikke funnet systematiske forskjeller mellom bydelene i fremmøte.

Tabell 1. Demografiske og biologiske karakteristika, deltakere i basisundersøkelsen i MoRo-prosjektet i 2000.

\begin{tabular}{lccc}
\hline & $\begin{array}{c}\text { Intervensjon } \\
(\mathrm{N}=1497)\end{array}$ & $\begin{array}{c}\text { Kontroll } \\
(\mathrm{N}=1453)\end{array}$ & p-verdi \\
\hline Alder (år) & 47,7 & 48,0 & $\mathrm{NS}$ \\
Kvinner (\%) & 57,2 & 55,7 & $\mathrm{NS}$ \\
Ikke-vestlige (\%) & 20,6 & 22,7 & $\mathrm{NS}$ \\
Utdanningslengde (år) & 11,6 & 12,2 & $<0,001$ \\
Diabetes (selvrapportert og & & & \\
udiagnostisert) (\%) & 7,2 & 6,2 & $\mathrm{NS}$ \\
Selvrapportert hjerteinfarkt (\%) & 2,3 & 1,5 & $\mathrm{NS}$ \\
Selvrapportert angina (\%) & 3,2 & 2,6 & $\mathrm{NS}$ \\
Inaktiv i fritiden (\%)* & 32,6 & 33,4 & $\mathrm{NS}$ \\
Dagligrøyking (\%) & 39,8 & 33,6 & $<0,01$ \\
Body mass index (kg/m $\left.{ }^{2}\right)$ & 27,0 & 26,6 & $<0,05$ \\
Fedme (BMI $>30)(\%)$ & 23,7 & 18,6 & $<0,001$ \\
Glukose (mmol/1) & 5,6 & 5,6 & $\mathrm{NS}$ \\
Totalkolesterol (mmol/1) & 5,7 & 5,6 & $\mathrm{NS}$ \\
HDL-kolesterol (mmol/l) & 1,40 & 1,41 & $\mathrm{NS}$ \\
Triglyserider (mmol/l) & 2,0 & 1,9 & $<0,05$ \\
\hline
\end{tabular}

* Andel som svarte ja på at de i hovedsak leste, så på TV og andre stillesittende aktiviteter i fritiden. 
Figur 1. Hovedkomponentene i intervensjonen* og eksposisjonstid i forhold til helseundersøkelsene.

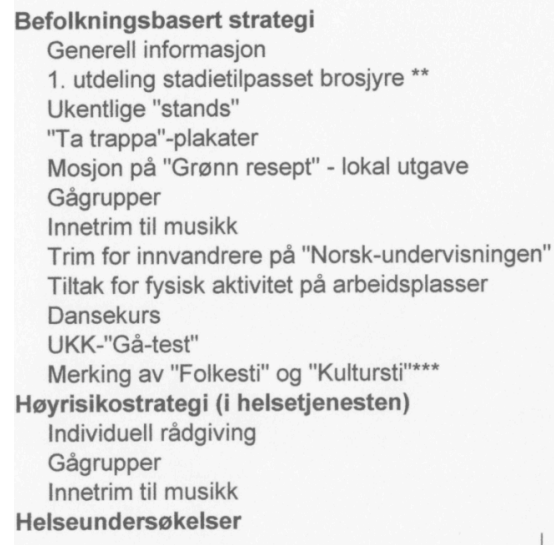

Árstall

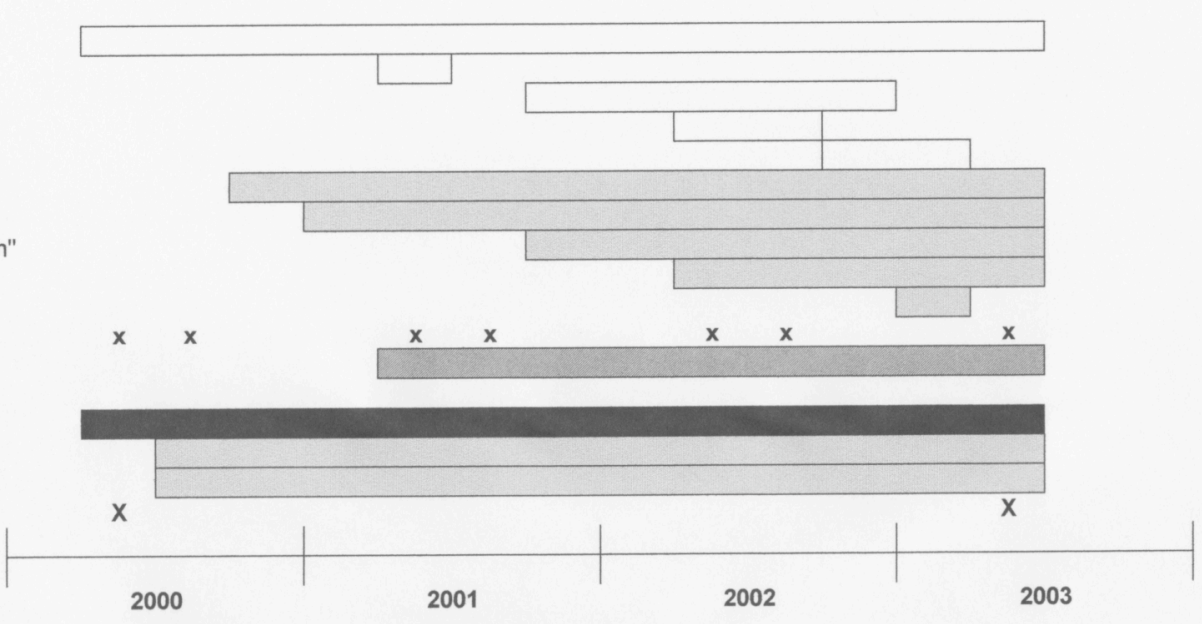

* Informasjonsaktiviteter (hvit), fysiske aktivitetsgrupper (lys grå), strukturelle aktiviteter (mørk grå), individuell rådgiving (sort)

** En brosjyre med stadietilpasset informasjon for å fremme fysisk aktivitet ble sendt til alle husstander

*** Inkluderte også bedre belysning, måking og strøing av gangveier om vinteren

\section{Diabetesforekomst, risikofaktorer og sosiale forskjeller}

Totalt hadde $5,1 \%$ av kvinnene og $9,0 \%$ av mennene diabetes. Mange av diabetestilfellene (32\% blant kvinnene, $44 \%$ blant mennene) var tidligere uoppdaget. Blant mennene med norsk bakgrunn var hele $50 \%$ av de påviste tilfellene tidligere uoppdaget. For flere av risikofaktorene var nivået høyere hos dem med tidligere uoppdaget enn med kjent diabetes (gjennomsnitt (SD)) (kolesterol 6,2 mmol/1 (1,1) versus 5,6 mmol/1 $(1,6), \mathrm{p}=0,003$, diastolisk blodtrykk $81,4 \mathrm{~mm} \mathrm{Hg}$ $(11,4)$ versus $75,6 \mathrm{~mm} \mathrm{Hg}(11,3), \mathrm{p}=0,001 \mathrm{og}$ systolisk blodtrykk 138,5 $\mathrm{mm} \mathrm{Hg}$ versus $132,9 \mathrm{~mm} \mathrm{Hg}$, $\mathrm{p}=0,06$ ). Bruk av blodtrykkssenkende medikamenter var lavere ved udiagnostisert enn kjent diabetes $(24,2 \%$ versus $30,8 \%, p<0,001)$, likeledes lipidsenkende medikamenter (10,3\% versus $24,4 \%, \mathrm{p}<0,001)$.

Den aldersjusterte diabetesprevalens for $30-67$ åringer med vestlig bakgrunn var 3,3\% (95\% KI 2,3$4,3)$ for kvinner og 7,2\% $(5,6-8,8)$ for menn. For sammenligninger mellom ulike etniske grupper brukes aldersgruppen 30-59 år (figur 2). Innvandrere fra SørAsia (det indiske subkontinent) hadde høyest forekomst av diabetes (kvinner 27,5\%, menn 14,3\%) (figur 2a). Andel med fedme varierte betydelig med etnisitet (figur 2b), og innvandrere fra Sør-Asia hadde størst tendens til sentral fedme (resultater ikke vist).

For alle mål på fysisk aktivitet i fritiden var mønsteret konsistent med en større andel fysisk inaktive innvandrere (51-64\%) enn vestlige (23-41\%, p <0,001). Etter justering for alder og midje/hofteratio var OR for diabetes hos innvandrere fra Sør-Asia i forhold til norske 7,7 (95\% KI 3,9-15,3) for kvinner og 2,6 (1,4-4,9) for menn. De etniske forskjellene var også signifikante og på samme nivå etter justering for fysisk aktivitet og utdanning. Etter ytterligere justering for kroppshøyde og for kvinner også for paritet var OR henholdsvis 6,0 $(2,3-15,4)$ og $1,9(0,9-4,0)$ (resultater ikke vist).
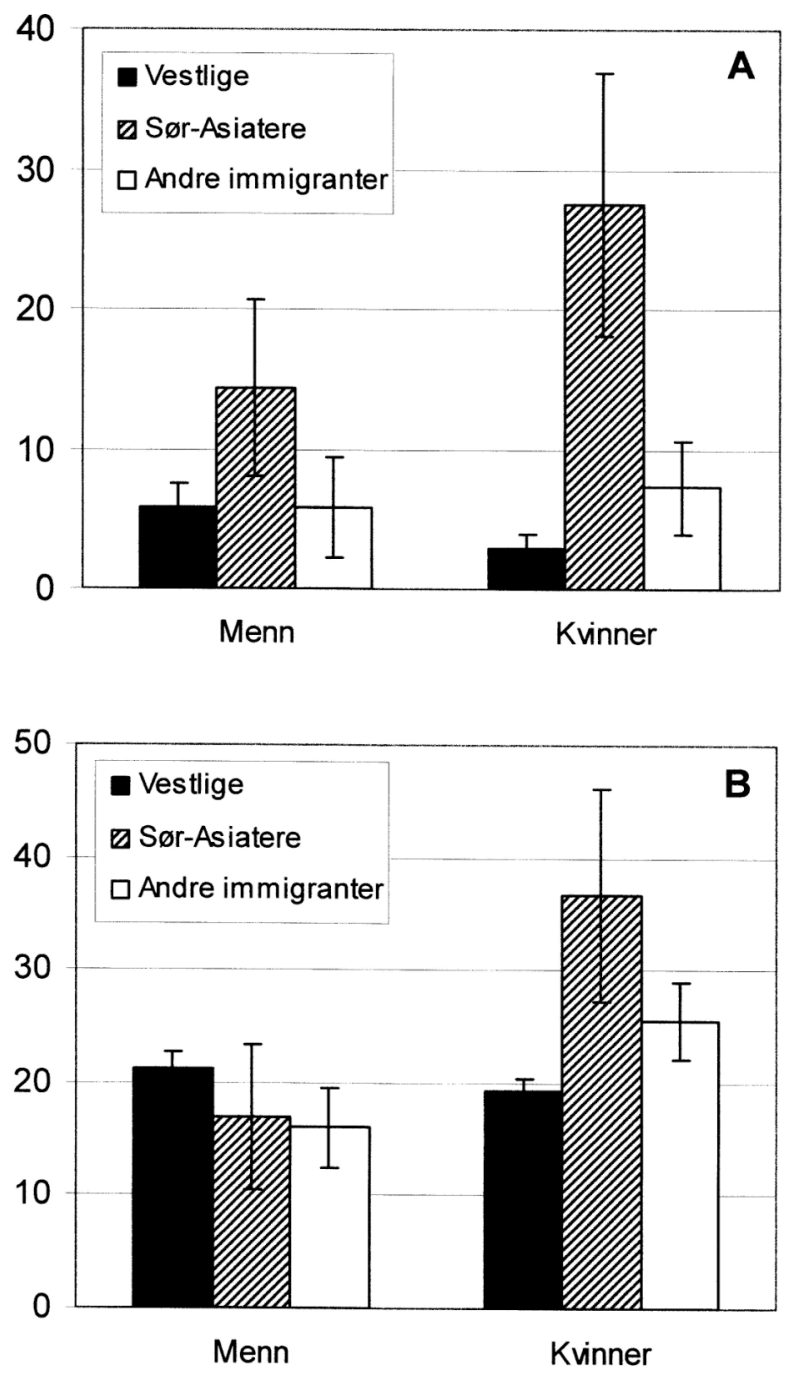

Figur 2. (a) Diabetesprevalens (\%, $95 \%$ konfidensintervall) i ulike etniske grupper. (b) Forekomst av fedme (BMI $>30$ $\left.\mathrm{kg} / \mathrm{m}^{2}\right)(\%, 95 \% \mathrm{KI})$ i ulike etniske grupper. 


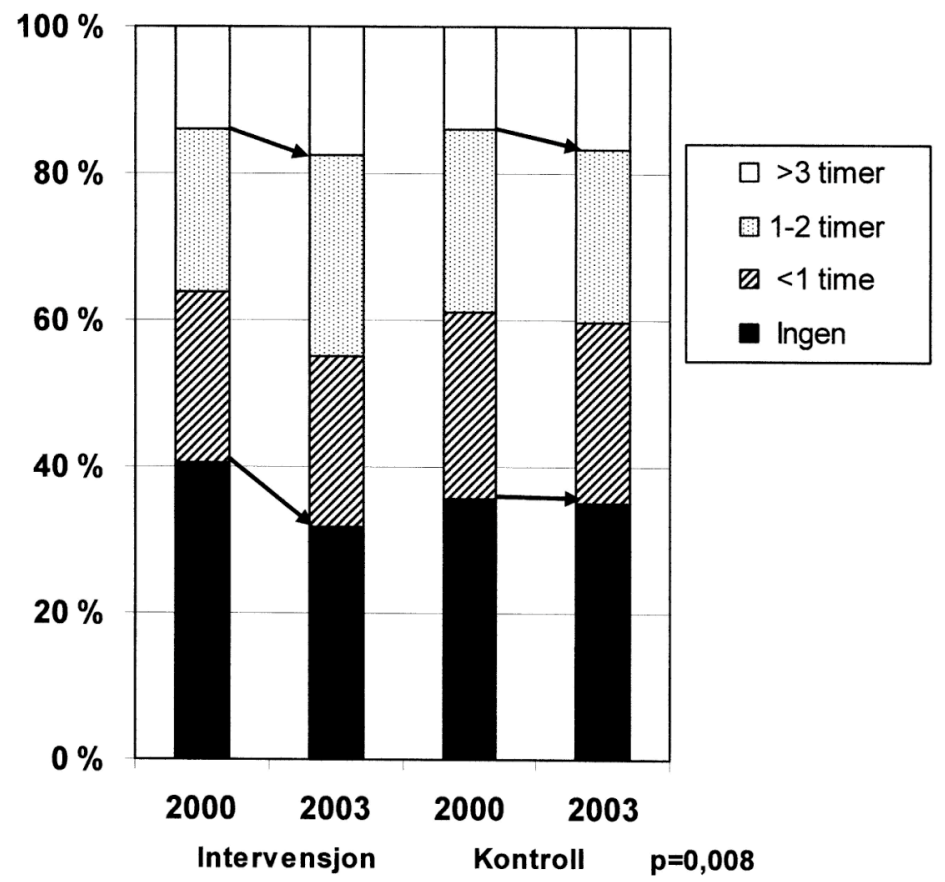

Figur 3. Endring i fysisk aktivitet fra 2000 til 2003, intervensjonsbydel versus kontrollbydel. Nettoforskjeller endring testet med Mann Whitney $(p=0,008)$.

En sterk invers assosiasjon mellom diabetes og utdanning ble funnet hos dem med vestlig bakgrunn (OR for kvinner: $0,53(0,27-1,03)$ for middels versus lavt utdanningsnivå og $0,33(0,14-0,78)$ for høyt versus lavt utdanningsnivå). En liknende, men ikke signifikant trend ble funnet hos innvandrere fra det indiske subkontinent. OR for diabetes ble gradvis redusert når inntektsnivået økte hos dem med vestlig bakgrunn. Effekten var sterkest for kvinner (OR 0,28 (0,14-0,57)) for midlere inntektsgruppe versus lav inntekt og 0,08 $(0,03-0,28)$ for høy versus lav inntekt. Tilsvarende tall for menn var henholdsvis $0,52(0,28-0,96)$ og 0,49 $(0,28-0,86)$. Hos innvandrere fra det indiske subkontinent var effekten av inntekt reversert, og økt inntekt økte risikoen for diabetes (OR 3,0 $(1,1-8,3)$ for midlere inntektsgruppe versus lav inntekt, og $1,9(0,6-5,7)$ for høy versus lav inntekt) (resultater ikke vist).

\section{Effekt av intervensjonen}

Ved oppfølgingsundersøkelsen møtte $67 \%$ av de innkalte i begge bydeler $(\mathrm{N}=1766)$. Færre ikke-vestlige innvandrere og dagligrøykere møtte fram på nytt $\mathrm{i}$ begge bydeler. De fremmøtte i intervensjonsbydelen var med de nevnte unntak representative for dem som møtte ved basisundersøkelsen, mens noe færre inaktive og fete møtte til oppfølgingsundersøkelsen i kontrollbydelen (resultater ikke vist).

Andel fysisk inaktive ble redusert fra $41 \%$ til $31 \%$ (relativ reduksjon $22 \%$ ) i intervensjonsbydelen, mens endringen i fysisk aktivitet var ubetydelig i kontrollbydelen (figur 3). Nettoendringen var signifikant også etter justering for forskjeller mellom bydelene ved basisundersøkelsen.
I begge bydeler økte gjennomsnittsvekten, men mindre i intervensjonsbydelen. Her gikk 38\% opp i vekt og 24\% reduserte sin vekt (nettoandel med vektøkning 14\%), mens tilsvarende tall i kontrollbydelen var henholdsvis $45 \%$ med vektøkning og $16 \%$ med vektreduksjon (nettoandel 29\%, p for bydelsforskjeller $<0,001)$. Andelen av befolkingen som gikk opp i vekt $\mathrm{i}$ intervensjonsbydelen ble redusert med $50 \%$ i forhold til kontrollbydelen (figur 4a). Bydelsforskjellen var signifikant også etter justeringer for forskjeller ved basisundersøkelsen. Utviklingen i vekt var uavhengig av utdanningsnivå og etnisitet, men var mer uttalt blant menn enn blant kvinner. Gunstige effekter ble funnet for kolesterol/HDL-kolesterol ratio, triglyserider og glukose, med det samme mønster for overnevnte subgrupper av befolkningen (figur $4 b$, figur $4 c$, figur $4 d$ ).

Nettoreduksjonen i systolisk blodtrykk var $3,8 \mathrm{~mm}$ $\mathrm{Hg}(1,8-5,7)$ hos menn og 3,5 mm Hg $(1,9-5,2)$ hos kvinner, og andelen dagligrøykere ble redusert mer enn i kontrollbydelen $(6,3 \%$ versus $3,4 \%, p=0,04)$. Dette gjaldt særlig for kvinner $<50$ år $(7,6 \%$ versus $0,8 \%$, $\mathrm{p}=0,001)$ (ikke vist i figur).

\section{DISKUSJON}

Ved studiestart var intervensjons- og kontrollgruppen sammenlignbare for en rekke demografiske og helserelaterte variabler, men flere i intervensjonsbydelen hadde uføretrygd, var dagligrøykere og hadde kroppsmasseindeks $>30 \mathrm{~kg} / \mathrm{m}^{2}$. Forekomsten av diabetes, fedme og fysisk inaktivitet var høy sammenlignet med tidligere norske studier (24). Diabetesforekomsten er underestimert da glukosebelastning ikke ble foretatt. 


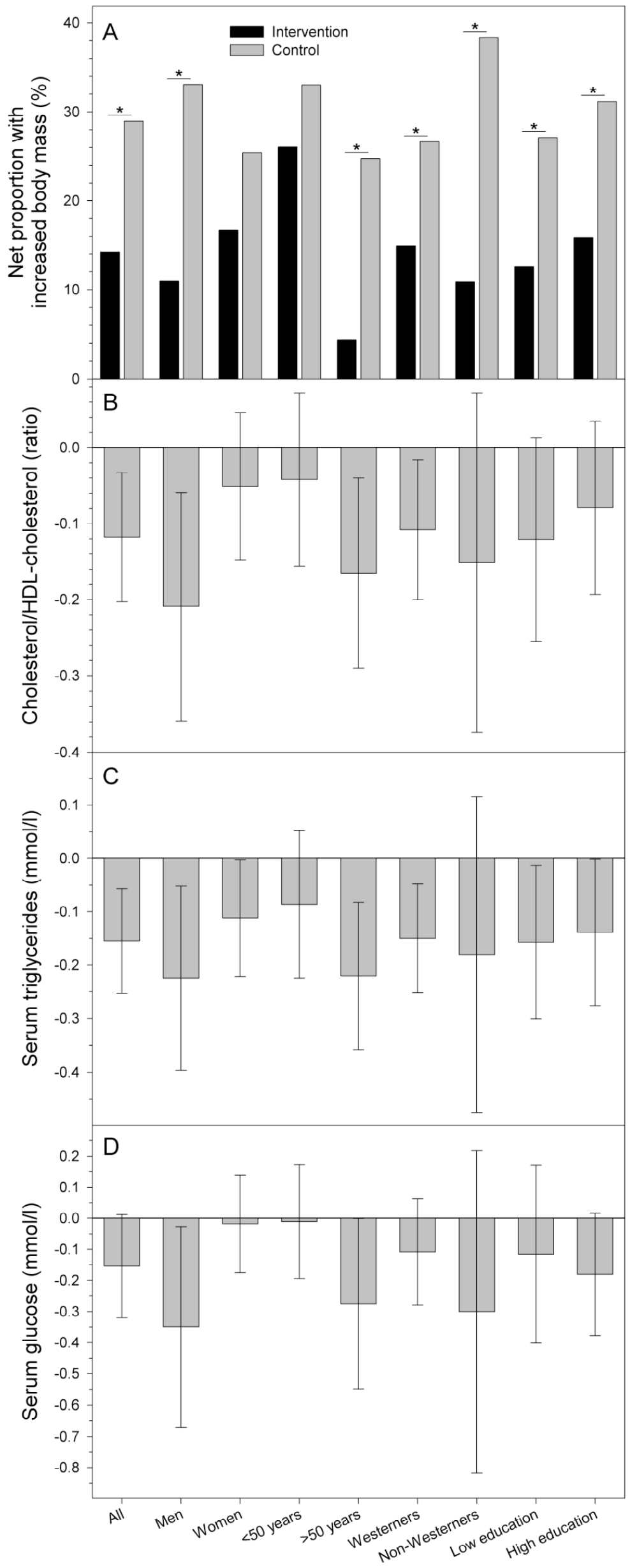

Figur 4. Netto andel med vektøkning pr bydel (a) og netto endring (forskjell mellom endringer $i$ intervensjons- og kontrollbydel samlet og i subgrupper, 95\% KI) i kolesterol/HDL-kolesterol-ratio (b), triglyserider (c) og glukose (d). Vektendring ble kategorisert: økning ( $>2 \mathrm{~kg}$ ), stabil, eller reduksjon $(>2 \mathrm{~kg})$, og andel med reduksjon ble fratrukket andel med økning. Nettoforskjellen mellom bydelene ble testet med Mann Whitney (*: $p<0,01)$. Ikkefastende blodprøver ble justert for tid siden siste måltid både i 2000 og i 2003 (ANOVA) og nettoendring ved regresjonsanalyser. Gjengitt med tillatelse fra Diabetes Care.

Store forskjeller mellom etniske grupper og kjønn ble funnet. Forekomsten av diabetes var særlig høy hos kvinner $(27,5 \%)$ og menn $(14,3 \%)$ fra det indiske subkontinent, også sammenlignet med andre studier av immigranter i Europa og fra deres hjemland (25, 26). OR for diabetes var betydelig høyere for disse innvandrergruppene sammenlignet med norske menn og kvinner også etter justering for sosioøkonomiske og atferdsrelaterte faktorer. Resultatene har bidratt til å sette type 2 diabetes, og uoppdaget diabetes, høyere på den helsepolitiske agendaen i Norge (27). Funnene indikerer videre at type 2 diabetes kan anses som en relevant sykdomsmarkør for sosiale helseforskjeller. Effekten av utdanning og inntekt hos norskfødte deltakere var særlig stor hos kvinner. Utdanning synes å ha en beskyttende effekt også hos innvandrere, mens økt inntekt fremsto som en risikofaktor hos dem fra det indiske subkontinent. Dette må ses i sammenheng med at høyinntektsgrupper og bysamfunn i deres hjemland først rammes av velstandssykdommer som type 2 diabetes og hjerte- og karsykdom (28). I Oslo lever ulike etniske sub-populasjoner side om side i ulike faser av den epidemiologiske transisjon.

Etter tre års intervensjon for å fremme fysisk aktivitet var andelen inaktive redusert med $22 \%$, og andelen som gikk opp i vekt var redusert med $50 \%$ i intervensjonsbydelen i forhold til i kontrollbydelen. Sammenlignet med målsettingen for US Healthy People 2010 , som er å redusere andelen inaktive fra $40 \%$ i 2000 til $20 \%$ i 2010 , oppnådde studien nær $50 \%$ av 10- årsmålsettingen i løpet av tre år (21). Det at like store effekter ble observert hos dem med høy og lav utdanning, og hos norske og hos ikke-vestlige innvandrere, er også uvanlig og er blitt lagt merke til internasjonalt (www.health-inequalities.org). Gunstige resultater ble også funnet for andre risikofaktorer som systolisk blodtrykk, glukose, lipider og andel dagligrøykere. Deltaker- 
nes evaluering av prosjektet og dets betydning var også svært positiv, og medieomtalen av Romsås er vesentlig mer balansert nå enn tidligere. De vesentligste suksessfaktorer synes å være at intervensjonen ble utviklet på grunnlag av et bredt teorigrunnlag hvor aktiv involvering av befolkningen også inngår. Dette kan ha bidratt til at kontekstuelle faktorer som sosiale kapital, kollektive mestringsforventninger og opplevelse av sammenheng også er blitt styrket (15). Den samlede effekt av disse endringer antas å kunne ha potensial til å påvirke fremtidig sykdomsforekomst.

MoRo-studiens begrensninger er knyttet til det relativt lave fremmøtet ved basisundersøkelsen og til at et ikke-randomisert design er brukt (9). Studien har et eksperimentelt design som var hensiktsmessig og akseptabelt da hovedmålet var å utvikle og evaluere nye metoder i lokalt folkehelsearbeid initiert $\mathrm{i}$ en bydel $(29,30)$. Det lave fremmøtet ved basisundersøkelsen tilsier at prevalensestimatene er noe usikre, selv om de kan være rimelig robuste selv ved lavt fremmøte (14). Høy forekomst av selvrapportert diabetes og fedme er funnet ved etterfølgende undersøkelser i andre fylker (www.fhi.no). Vi anser fremmøtet ved oppfølgingsundersøkelsen (67\%) som akseptabelt $i$ en urban, multietnisk befolkningsbasert studie av tre års varighet. Detaljerte frafallsanalyser er foretatt, og den sannsynlige effekt av mulige seleksjonsbias er drøftet $(9,15)$. Selv om potensialet for effekt er større der risikofaktornivået er høyest, regnes det som mer utfordrende å skape endring i grupper med lav sosioøkonomisk status (21). En viss smitteeffekt av intervensjonen til kontrollbydelen synes også å ha funnet sted. Etter en samlet vurdering antar vi at effektene heller er under- enn overestimert (15).

\section{Implikasjoner for fremtidig folkehelsearbeid for å redusere sosiale helseforskjeller}

Den sosiale gradient i totaldødelighet i Norge vil neppe avta vesentlig før forekomsten og dødeligheten av hjerte- og karsykdom også reduseres i grupper med lav sosioøkonomisk status (31). Nasjonale strategier i forhold til sosiale helseforskjeller og folkehelsearbeid må i fremtiden også rettes inn mot fedme- og inaktivitetsepidemien og disse faktorers sosiale determinanter. En rettferdig og virkningsfull fordelingspolitikk som virker tidlig i årsakskjeden, er åpenbart viktig og nødvendig, likeledes en målrettet nasjonal strategi og plikt til konsekvensutredninger om hvordan politikk, tiltak og prosjekter vil påvirke gradienten $(2,32,33)$. Vi betviler imidlertid at dette alene vil ha tilstrekkelig effekt på diabetesepidemien og dennes sosiale gradient. Grunnlaget for god helse legges i tidlige barneår (5). Den høye forekomsten av diabetes og fedme hos kvinner $\mathrm{i}$ fertil alder i enkelte innvandrergrupper i Norge er særlig bekymringsfull $(9,16)$, da den kan ha intergenerasjonelle effekter (34). Vi mener at det foreligger et sterkt rasjonale for at målrettet innsats i områder med spesielle helse- og levekårsutfordringer bør inngå i en nasjonal strategi $(3,30)$. Disse områdene burde ha landets beste barnehager og skoler, men også langsiktige, kunnskapsbaserte folkehelseprogrammer i pakt med dagens utfordringer som supplement til strukturelle tiltak, gjennom virkning senere $\mathrm{i}$ årsakskjeden. Omprioriteringer innen helsetjenesten, bl.a. for tidligere diagnostikk av diabetes, for å optimalisere behandling og egen mestring av diabetes og hjerte- og karsykdom, samt individuell forebygging ved høy sykdomsrisiko, er også virkemidler som kan motvirke de helsemessige konsekvenser av sosial ulikhet enda senere i årsakskjeden $(3,4)$. Slike tiltak anses også kostnadseffektive (35).

Evalueringene av flere store, randomiserte, populasjonsbaserte intervensjoner overfor hjerte- og karsykdommer har vist at det kan være vanskelig å etterspore langtidseffekter av spesifikke intervensjonstiltak mens trendene for risikofaktorer er fallende (36). Det vil imidlertid være lettere å vise effekt av befolkningsstrategier overfor risikofaktorer som er økende, for å begrense hastigheten i økningen eller "epidemiens" fremtidige toppnivå. I forhold til sosiale helseforskjeller vil de potensielle langtidseffektene være særlig store dersom man kan begrense en fortsatt økning i risikofaktorer som særlig rammer grupper med lav sosial status.

Man har i dag en bredere teoretisk forståelse av hvordan samspillet mellom individ og miljø i vid forstand gjennom livsløpet påvirker atferd $(4,5)$. Intervensjoner bør rettes inn mot miljømessige determinanter for atferd på flere samfunnsnivåer, også fysiske og sosiale forhold på arbeidsplasser og i lokalsamfunn, og i mindre grad mot enkeltindivider alene hvis atferd innebærer økt sykdomsrisiko. En kombinasjon av høyrisikostrategi (innenfor helsetjenesten) og befolkningsstrategi vil kunne ha synergieffekter (35).

\section{Et nytt kompetansesenter for intervensjonsforskning?}

De store sosialt betingede helseforskjellene i Norge, og ikke minst i Oslo, representerer en nasjonal helsepolitisk utfordring (7). I Groruddalen kan vi nå observere raske demografiske endringer, med en sterk økning av andelen ikke-vestlige innvandrere (www.ssb.no). Dette området (ytre øst) har også en mer ugunstig utvikling for fedme og fysisk inaktivitet enn regionene indre øst og vest og ytre vest (Jenum AK, innsendt 2006). MoRo-prosjektet har dokumentert også andre helseutfordringer i området, som en høy forekomst av kjent og uoppdaget diabetes. Intervensjonsstudiens positive effekter ønskes nå videreført (www.statsbudsjettet.dep. no/Statsbudsjettet-2007/). Dette bør skje i nye modellprosjekter hvor adekvat evaluering er integrert. Disse bør utvikles og implementeres etter en helhetlig plan, og $\mathrm{i}$ et formalisert samarbeid mellom berørte bydeler, nasjonale helsemyndigheter og forskningsmiljøer. Men ansvaret for intervensjonsforskningen innenfor folkehelsefeltet generelt, og overfor sosiale helseforskjeller 
spesielt, må etter vårt syn også organisasjonsmessig forankres, om nødvendig gjennom etablering av et nytt kompetansesenter. Dette vil kunne bidra til å utvikle mer fremtidsrettede og effektive tiltak overfor de folkehelseutfordringene vi står overfor. Vi vet at selv en beskjeden, men gunstig påvirkning i en risikofaktor som angår mange, vil på befolkningsnivå kunne gi en betydelig effekt på dødeligheten (37). WHO har nylig lansert begrepet "unngåelig sykdomsbyrde", som estimerer effekten av ulike og i prinsippet oppnåelige eller erfaringsbaserte prosentvise reduksjoner i risikofordelingen i befolkningen (10). Hvilken reduksjon i sykelighet eller dødelighet vil vi kunne oppnå om andelen dagligrøykere eller andel inaktive $\mathrm{i}$ befolkningen generelt, eller i grupper med lav sosioøkonomisk status spesielt, ble redusert med $10 \%$ eller $30 \%$ i forhold til dagens nivå? Hva vil kostnadene ved ulike strategier og ambisjonsnivåer være? En slik strategi vil kunne bedre kunnskapsgrunnlaget for å identifisere de mest effektive folkehelsestrategier også $\mathrm{i}$ forhold til sosiale helseforskjeller.

\section{KONKLUSJON}

MoRo-prosjektet har vist at det er mulig å øke fysisk aktivitetsnivå og redusere dagligrøyking og biologiske risikofaktorer for hjerte- og karsykdom og diabetes i et lokalsamfunn med høy dødelighet og lav sosioøkonomisk status ved en teoribasert og lokalt initiert lavkostnadsintervensjon med en kombinert befolkningsrettet og høyrisikorettet strategi. Intervensjonseffektene var like store hos grupper med høy som lav utdanning, og hos ikke-vestlige innvandrere som hos norskfødte. I en nasjonal strategi for å redusere sosiale helseforskjeller bør lokale, kunnskapsbaserte tiltak på flere nivåer også inngå, eventuelt med ulik intensitet, for å bidra til å redusere de lokale og regionale gradientene. Dette krever metodeutvikling og evaluering som må finansieres gjennom nasjonal prioritering av intervensjonsforskning. Diabetes (type 2) kan anses som markør for sosiale helseforskjeller. Overvåkning av forekomsten i ulike sosiale grupper bør inngå i oppfølgingen av en nasjonal strategi.

\section{REFERANSER}

1. Pedersen JI, Tverdal A, Kirkhus B. Kostendringer og dødelighetsutvikling av hjerte- og karsykdommer i Norge. Tidsskr Nor Loegeforen 2003; 124: 1532-1536.

2 Sund E, Krokstad S. Sosiale ulikheter i helse i Norge. En kunnskapsoversikt. Oslo: Sosial- og helsedirektoratet, 2005.

3. Avendano M, Kunst AE, Huisman M, et al. Socioeconomic status and ischaemic heart disease mortality in 10 western European populations during the 1990s. Heart 2006; 92: 461-467.

4. Davey Smith G. Health inequalities. Lifecourse approaches. Bristol: The Policy Press, 2003.

5. Kuh D, Ben-Shlomo Y. A Life Course Approach to Chronic Disease Epidemiology. New York: Oxford University Press, 2004.

6. Rognerud M, Stensvold I. Oslohelsa. Utredning om helse, miljø og sosial ulikhet i bydelene. Oslo: Klinikk for forebyggende medisin, 1998.

7. Jenum AK, Stensvold I, Thelle DS. Differences in cardiovascular disease mortality and major risk factors between districts in Oslo. An ecological analysis. Int J Epidemiol 2001; 30 Suppl 1: S59-S65.

8. Jenum AK, Birkeland K. 'Mosjon på Romsås' (MoRo) - et helsefremmende intervensjonsprosjekt for å fremme fysisk aktivitet $i$ et multi-etnisk lokalsamfunn i Oslo øst. Norsk Epidemiologi 2003; 13: 55-64.

9. Jenum AK. A public health approach to the prevention of type 2 diabetes and cardiovascular disease. Background, methods and results of the "Romsås in Motion" community-based intervention study. Oslo: Diabetes Research Centre, Aker and Ullevål University Hospitals, Faculty of Medicine, University of Oslo, 2006.

10. World Health Report 2002. Reducing risks, promoting healthy lives. Geneve: WHO, 2002.

11. Zimmet P, Alberti KG, Shaw J. Global and societal implications of the diabetes epidemic. Nature 2001; 414: $782-787$.

12. Haffner SM, Lehto S, Ronnemaa T, Pyorala K, Laakso M. Mortality from coronary heart disease in subjects with type 2 diabetes and in nondiabetic subjects with and without prior myocardial infarction. $N$ Engl J Med 1998; 339: 229-234.

13. Jenum AK, Lorentzen C, On behalf of the MoRo-study group. Promoting physical activity in at multi-ethnic district - methods and baseline results of a pseudo-experimental intervention study. Eur J Cardiovasc Prev Rehabil 2003; 10: 387-396.

14. Sogaard AJ, Selmer R, Bjertness E, Thelle D. The Oslo Health Study: The impact of self-selection in a large population-based survey. Int J Equity Health 2004; 3: 3.

15. Jenum AK, Anderssen SA, Birkeland KI, et al. Promoting physical activity in a low-income multiethnic district: effects of a community intervention study to reduce risk factors for type 2 diabetes and cardiovascular disease: a community intervention reducing inactivity. Diabetes Care 2006; 29: 1605-1612. 
16. Jenum AK, Holme I, Graff-Iversen S, Birkeland K. Ethnicity and sex are strong determinants of diabetes in an urban Western society: implications for prevention. Diabetologia 2005; 48: 435-439.

17. Sallis JF, Owen N. Physical Activity \& Behavioural Medicine. London: Sage Publications, 1999.

18. Bandura A. Social Foundations of Thought and Action. A Social Cognitive Theory. Englewood Cliffs, New Jersey: Prentice-Hall, 1986.

19. Ajzen I, Madden T. Prediction of goal-directed behavior. Attitudes, intentions and perceived behavioral control. J Exp Soc Psychol 1986; 22: 453-474.

20. Anderson D, Cychosz C. Exploration of the relationship between exercise behavior and exercise identity. $J$ Sport Behav 1995; 18: 159-166.

21. Kahn EB, Ramsey LT, Brownson RC, et al. The effectiveness of interventions to increase physical activity. A systematic review. Am J Prev Med 2002; 22: 73-107.

22. Prochaska J, Marcus BH. The transtheoretical model: Applications to exercise. I: Advances in Exercise Adherence. Dishman RK, red. Georgia: University of Georgia, 1994: 161.

23. Campbell C, Jovchelovitch S. Health, community and development: Towards a social psychology of participation. J Community Appl Soc Psychol 2000; 10: 255-270.

24. Midthjell K, Kruger O, Holmen J, et al. Rapid changes in the prevalence of obesity and known diabetes in an adult Norwegian population. The Nord-Trondelag Health Surveys: 1984-1986 and 1995-1997. Diabetes Care 1999; 22: 1813-1820.

25. Bhopal R, Unwin N, White M, et al. Heterogeneity of coronary heart disease risk factors in Indian, Pakistani, Bangladeshi, and European origin populations: cross sectional study. BMJ 1999; 319: 215-220.

26. Qiao Q, Hu G, Tuomilehto J, et al. Age- and sex-specific prevalence of diabetes and impaired glucose regulation in 11 Asian cohorts. Diabetes Care 2003; 26: 1770-1780.

27. Resept for et sunnere Norge. Folkehelsepolitikken. St.meld. nr. 16 (2002-2003). Oslo: Helse- og omsorgsdepartementet, 2003.

28. Ramachandran A, Snehalatha C, Latha E, Vijay V, Viswanathan M. Rising prevalence of NIDDM in an urban population in India. Diabetologia 1997; 40: 232-237.

29. Mackenbach JP, Bakker MJ. Tackling socioeconomic inequalities in health: analysis of European experiences. Lancet 2003; 362: 1409-1414.

30. Mackenbach JP. Tackling inequalities in health: the need for building a systematic evidence base. J Epidemiol Community Health 2003; 57: 162.

31. Mackenbach JP, Bos V, Andersen O, et al. Widening socioeconomic inequalities in mortality in six Western European countries. Int J Epidemiol 2003; 32: 830-837.

32. Nasjonal strategi for å utjevne sosiale helseforskjeller. St.meld. nr. 20 (2006-2007). Oslo: Helse- og omsorgsdepartementet, 2007.

33. Fosse E. Sosial ulikhet som tema i helsekonsekvensutredninger. Verktøy og erfaringer i noen europeiske land. Oslo: Sosial- og helsedirektoratet, 2006.

34. Catalano PM. Obesity and pregnancy - the propagation of a viscous cycle? J Clin Endocrinol Metab 2003; 88: $3505-3506$.

35. Tuomilehto J. Programme for the Prevention of Type 2 Diabetes in Finland. Jyväskylä, Finland: Finnish Diabetes Association, 2003.

36. Mittelmark MB. Health promotion at the communitywide level. Lessons from diverse perspectives. In Health Promotion at the Community Level. 2. New Advances. Bracht N, red. London: Sage Publications, 1999: 3-27.

37. Rose G: The Strategy of Preventive Medicine. Oxford: Oxford University Press, 1999. 